\title{
Strategic Renewal: Past Research, Theoretical Tensions and Future Challenges
}

\author{
Achim Schmitt, Sebastian Raisch ${ }^{1}$ and Henk W. Volberda ${ }^{2}$ \\ Ecole hôtelière de Lausanne, HES-SO // University of Applied Sciences Western Switzerland, Route de Cojonnex 18, \\ 1000 Lausanne 25, Switzerland, ${ }^{1}$ University of Geneva, Geneva School of Economics and Management, Blvd. du Pont \\ d'Arve 40, 1211 Geneva, Switzerland, and ${ }^{2}$ Erasmus University, Rotterdam School of Management, 3062 PA \\ Rotterdam, The Netherlands \\ Corresponding author email: Achim.Schmitt@ehl.ch
}

\begin{abstract}
Strategic renewal has become a prominent theme in a variety of organization and management research domains in recent years. It refers to the process that allows organizations to alter their path dependence by transforming their strategic intent and capabilities. With contributions from an increasing range of theoretical perspectives and research contexts, the strategic renewal literature has become fragmented and lacks common definitions and conceptual clarity, which prevent cross-fertilization and harm further development. This study systematically reviews the various literature streams on strategic renewal to provide a more integrative perspective. The authors identify three key theoretical tensions at the heart of strategic renewal research, namely learning vs. resource, induced vs. autonomous, and co-alignment vs. co-creation. By exploring these key tensions, the authors define strategic renewal's conceptual core, identify gaps in the past literature, and provide guidance for future research.
\end{abstract}

\section{Introduction}

Today's organizations face increasingly dynamic environments, characterized by substantial and often unpredictable technological, political and economic change. Strategic renewal research analyses how these organizations alter their path dependence by transforming their strategic intent and capabilities (Albert et al. 2015; Flier et al. 2003; Huff et al. 1992). The recognition, formulation and execution of these transformation processes are central issues pertinent to this literature (Basu and Wadhwa 2013; Ben-Menahem et al. 2013; Kwee et al. 2011). Since most organizations need to transform themselves at one time or another, strategic renewal is a key consideration in understanding their long-term survival and prosperity.

Strategic renewal is a prominent theme in various organization and management research domains.
Scholars have explored the managerial cognitions, capabilities and learning processes underlying firms' strategic renewal efforts (Crossan and Berdrow 2003; Dougherty 1992; Salvato 2009); the importance of political, technological and competitive changes in the firm's environment for strategic renewal (Flier et al. 2003; Kim and Pennings 2009; Volberda and Lewin 2003); as well as the organizational, unitlevel and team-level structures and processes that enable firms to embrace and manage strategic renewal (Cho and Hambrick 2006; Eggers and Kaplan 2009; Tippmann et al. 2014).

The broad attention paid to strategic renewal signals a vibrant and flourishing research domain. However, increasing breadth also means a growing diversity in theoretical perspectives and empirical contexts, which creates a number of challenges that hinder the field's advancement. First, theoretical pluralism has not only led to incongruent definitions

This is an open access article under the terms of the Creative Commons Attribution-NonCommercial-NoDerivs License, which permits use and distribution in any medium, provided the original work is properly cited, the use is non-commercial and no modifications or adaptations are made.

(C) 2016 The Authors

International Journal of Management Reviews published by British Academy of Management and John Wiley \& Sons Ltd. Published by John Wiley \& Sons Ltd, 9600 Garsington Road, Oxford OX4 2DQ, UK and 350 Main Street, Malden, MA 
and assumptions (Agarwal and Helfat 2009), but has also blurred the field's conceptual boundaries (Schmitt et al. 2016). Second, multiple theoretical tensions arise from different, partly contradictory, assumptions and findings. For instance, certain studies consider strategic renewal a purposive process with a clear beginning and an end (Stopford and BadenFuller 1994), while other scholars describe strategic renewal as a relentless search to adjust a firm's strategic intent and capabilities (Ravasi and Lojacono 2005). Third, the theoretical tensions cause scholars to make only partial use of prior findings, which hinders cumulative knowledge-building. For instance, Volberda and Lewin (2003) conclude that renewal studies have become difficult to compare, aggregate and replicate.

We therefore believe that examining the tensions between different theoretical perspectives on strategic renewal could be a powerful way to synthesize prior research and develop it further. ${ }^{1}$ A systematic literature review allows us to evaluate the research field's status quo in a 'replicable, scientific, and transparent process' (Tranfield et al. 2003, p. 209). Such a review ensures that this extensive, yet diverse, body of work becomes more complementary, synergistic and cumulative. Moreover, exploring tensions is an important way of stimulating the development of more encompassing and relevant theories (Lewis and Grimes 1999; Poole and Van de Ven 1989). Overall, our aim is thus to take stock of past strategic renewal research to provide future research with a foundation that provides greater conceptual clarity and theoretical integration, while acknowledging the field's diversity and richness.

We progress in three main steps. After briefly outlining our methodology, we first draw on key contributions in the field to clarify strategic renewal's definition and establish its boundaries to related concepts. Second, we discuss three key theoretical tensions at the heart of strategic renewal research, namely learning vs. resource, induced vs. autonomous, and co-alignment vs. co-creation. These tensions help us structure prior work and identify its communalities and contradictions. Finally, we conclude by presenting avenues for future research to overcome these tensions and use them as stimuli for more integrative research.

\footnotetext{
${ }^{1}$ We would like to thank one of the reviewers for this suggestion.
}

\section{Methodology}

Our literature review followed the systematic process described by Denyer and Tranfield (2008) and Macpherson and Jones (2010). We built a comprehensive database by selecting relevant articles in various steps. First, we searched the Web of Science database, which provides bibliographic information on more than 50 disciplines. Although practitioners had previously used the term 'strategic renewal' (e.g. Haggerty 1969), we focused our search on English-language articles published after Burgelman's seminal article in 1983; which had triggered academic interest. Our search therefore covers 33 years of strategic renewal research (1983-2015). We further focused on journals in the 'Business and Economics' category of the Web of Science database. Within these journals, we searched for the title and topic fields by means of the primary Boolean search term 'renewal AND strat*', as well as the additional search terms 'renewal AND org*' and 'renewal AND self*'. We included the two additional search terms, because several scholars had used the alternative terms 'self-renewal' (e.g. Chakravarthy 1984; Jaw and Liu 2003) and 'organizational renewal' (e.g. Barr et al. 1992; Peltola 2012). Later studies generally treated these terms as synonyms for strategic renewal (e.g. Basu and Wadhwa 2013). The initial Web of Science database search yielded 940 articles.

Second, we shortened our initial sample. Given that we wanted to identify the core studies on strategic renewal, we decided to consider only articles published in journals with 2015 Journal Citation Report impact factors of 1.0 and above. This led to a shortened sample of 298 studies. In a next step, two of the authors independently reviewed all the remaining studies to determine whether they covered topics related to strategic renewal. If the two authors disagreed, the third author was consulted. We also excluded research notes and dialogue papers. This identification process resulted in a set of 91 core publications on strategic renewal.

Third, to mitigate the potential risk of excluding key articles, we conducted independent literature searches of the Business Source Premier, Google Scholar and JSTOR databases. The results were highly consistent with our initial findings. Most of the additional articles found were working papers, non-peer-reviewed articles and papers published in journals outside our search scope. However, we found four additional papers that fulfilled all our initial search criteria, but 
Table 1. List of journals used in the systematic review, articles per journal and ISI Impact Factor 2015

\begin{tabular}{|c|c|c|}
\hline Journal Name & Total count & Impact Factor 2015 \\
\hline Long Range Planning & 14 & 2.718 \\
\hline Strategic Management Journal & 12 & 3.341 \\
\hline Organization Science & 9 & 3.775 \\
\hline Journal of Management Studies & 7 & 3.763 \\
\hline Academy of Management Review & 5 & 7.475 \\
\hline Small Business Economics & 5 & 1.795 \\
\hline Journal of Business Research & 3 & 1.480 \\
\hline European Management Journal & 3 & 1.222 \\
\hline Business Horizons & 3 & 1.163 \\
\hline Journal of Business Venturing & 2 & 3.678 \\
\hline Entrepreneurship Theory \& Practice & 2 & 3.144 \\
\hline Organization Studies & 2 & 2.886 \\
\hline Technovation & 2 & 2.526 \\
\hline Asia Pacific Journal of Management & 2 & 2.091 \\
\hline Journal of Product Innovation Management & 2 & 1.696 \\
\hline British Journal of Management & 2 & 1.584 \\
\hline Harvard Business Review & 2 & 1.574 \\
\hline Management Learning & 2 & 1.208 \\
\hline Academy of Management Journal & 1 & 6.448 \\
\hline Journal of International Business Studies & 1 & 3.563 \\
\hline Academy of Management Executive (now Perspectives) & 1 & 3.354 \\
\hline Administrative Science Quarterly & 1 & 3.333 \\
\hline Management Science & 1 & 2.482 \\
\hline Human Relations & 1 & 2.398 \\
\hline Journal of Engineering and Technology Management & 1 & 2.060 \\
\hline Technological Forecasting and Social Change & 1 & 2.058 \\
\hline International Small Business Journal & 1 & 1.800 \\
\hline Int. Journal of Operations \& Production Management & 1 & 1.736 \\
\hline MIT Sloan Management Review & 1 & 1.529 \\
\hline Entrepreneurship \& Regional Development & 1 & 1.519 \\
\hline Management Decision & 1 & 1.429 \\
\hline Strategic Organization & 1 & 1.400 \\
\hline Journal of Leadership \& Organizational Studies & 1 & 1.125 \\
\hline IEEE Transactions on Engineering Management & 1 & 1.103 \\
\hline Total & 95 & 2.890 \\
\hline
\end{tabular}

were not in the Web of Science database. After verifying their contents, we added these four papers to our final sample of 95 core publications (see Appendix S1). Given the broad scope of strategic renewal research, the articles reviewed had been published in journals representing a great variety of organization and management research domains (for an overview of these journals and articles, see Table 1).

The subsequent data analyses followed prior authors' approaches to conducting systematic literature reviews (Lee 2009; Stadler et al. 2014; Wang and Chugh 2014). The following thematic codes were used to code the articles (see Appendix S1): (1) Name of the author(s); (2) Year of publication; (3) Research focus; (4) Theoretical lens; (5) Methodology; and (6) Key findings. Given our emphasis on identifying theoretical tensions, we added an additional code - (7)
Key tensions - to capture the main controversies in the strategic renewal debate. The 95 articles in our final sample were then manually coded according to these seven predefined themes, which required careful reading and expert assessment. Similar to the abovementioned identification process, two authors independently read and coded each article according to the predefined themes. To ensure a high degree of inter-rater reliability, the two authors subsequently discussed any differences in the coding and recording. The third author was consulted if they disagreed.

Our sample includes 39 papers that analysed the strategic renewal concept theoretically and 56 papers that assessed it empirically. The empirical papers applied a wide range of methods, including qualitative and quantitative research designs as well as mixed methods (see Figure 1 as well as the 'Methodology' 


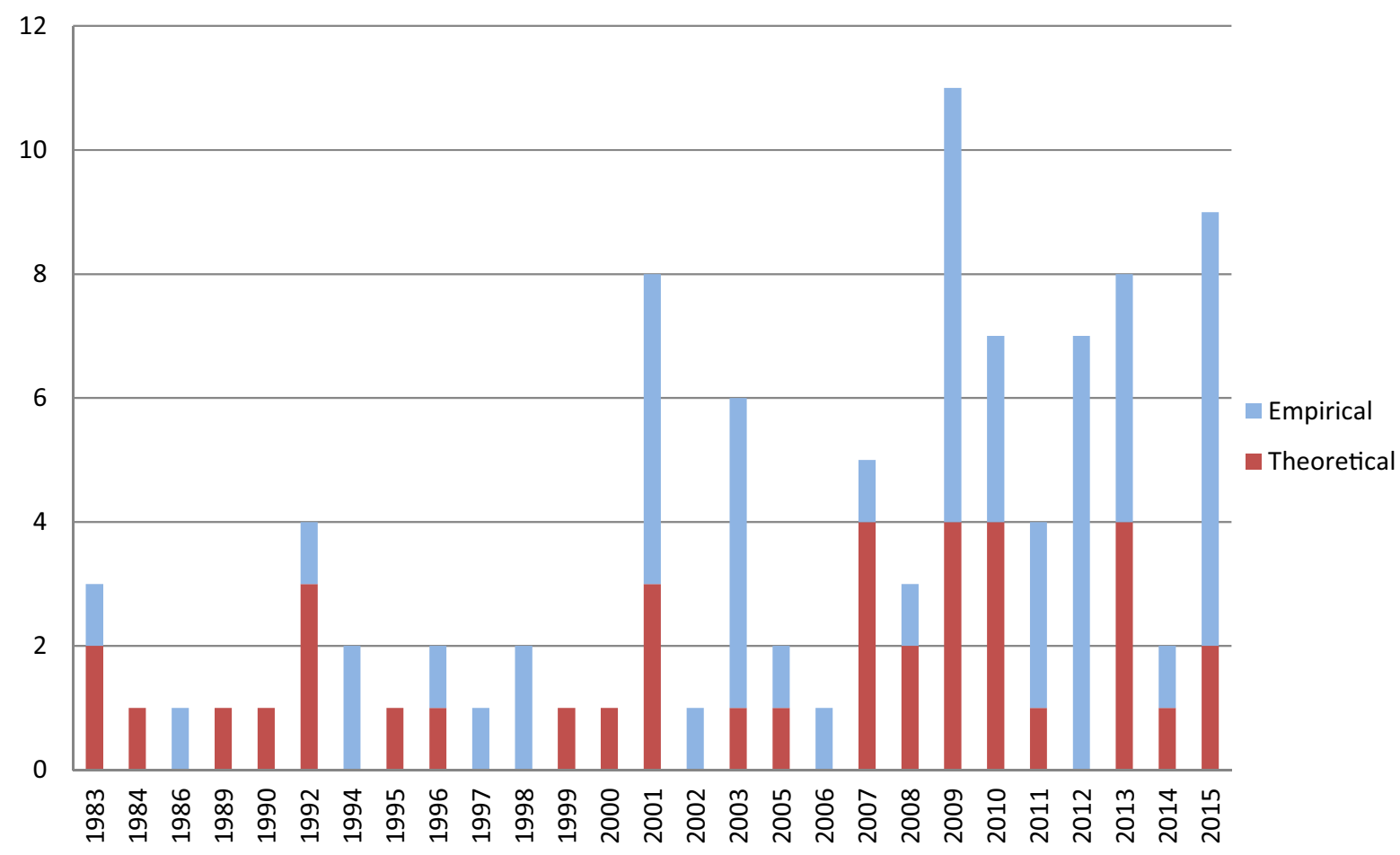

Figure 1. Strategic renewal publication distribution (1983-2015)

column in Appendix S1). The distribution between qualitative (26 articles) and quantitative studies (25 articles) is quite balanced (with the remaining five articles using mixed methods). The qualitative designs include multiple case studies (e.g. Danneels 2002; Flier et al. 2003; Miles et al. 2003) and in-depth single-case or ethnographic studies (e.g. Chakravarthy and Gargiulo 1998; Crossan and Berdrow 2003; Smits and Groeneveld 2001). Quantitative designs include longitudinal studies (e.g. BenMenahem et al. 2013; Kwee et al. 2011) and crosssectional studies (e.g. Burgers et al. 2009; Capron and Mitchell 2009).

\section{Definition and conceptual boundaries}

Following the systematic literature review process (Denyer and Tranfield 2008; Macpherson and Jones 2010), we start our review by clarifying the definition and conceptual boundaries. Despite its wide recognition and importance across various research domains, there is no consensus in the literature on what strategic renewal means and how it differs from other, related concepts, such as corporate entrepreneurship (Verbeke et al. 2007), strategic change
(Agarwal and Helfat 2009) and strategy process (Volberda and Baden-Fuller 2003). For instance, different studies in our review sample defined strategic renewal as a specific type of strategic change (Burgelman 1991), a managerial process promoting changes in a firm's core competences (Floyd and Lane 2000), the 'redefinition of a firm's mission' (Zahra 1993, p. 321), changes to the 'resource patterns of business' (Stopford and Baden-Fuller 1994, p. 522), the 'alignment of organizational competencies with the environment' (Flier et al. 2003, p. 2168) and the 'process, content, and outcome of refreshment and replacement (...) of organizational attributes' (Agarwal and Helfat 2009, p. 282). Some scholars acknowledge that renewal varies in terms of its success and therefore do not presuppose a specific outcome in their definition (Agarwal and Helfat 2009; Burgelman 1991; Floyd and Lane 2000). Other scholars' definitions stress the importance of the actual changes in terms of strategically relevant capabilities that result from strategic renewal efforts (e.g. Flier et al. 2003; Guth and Ginsberg 1990; Schmitt et al. 2016).

The different definitions of strategic renewal emerge in distinct theoretical debates, linking the concept to an evolutionary orientation (Floyd and Lane 2000; Lechner and Floyd 2012), to contingency 
arguments (Flier et al. 2003; Volberda et al. 2001b), cognitive elements (Barr et al. 1992; Stienstra et al. 2004), social exchange processes (Pappas and Wooldridge 2007; Prashantham 2008) and organizational capabilities (Ben-Menahem et al. 2013; Capron and Mitchell 2009). This conceptual pluralism is further strengthened by the wide range of distinct empirical contexts and levels of analysis describing strategic renewal as the outcome of activities related to inter-firm collaborations (Makri et al. 2010; Thorgren et al. 2010), top management teams (Hurst et al. 1989; Kor and Mesko 2013), middle managers (Floyd and Wooldridge 1997; Lindell 1986), venture teams (Basu and Wadhwa 2013; Salvato 2009) and firm employees (Chakravarthy and Gargiulo 1998; De Clercq et al. 2011).

In short, previous literature agrees to disagree on the meaning of the term 'strategic renewal'. The term has been freely applied within the different theoretical debates, research domains and empirical contexts. However, the field would certainly benefit from greater conceptual clarity (Agarwal and Helfat 2009), which could enable cross-fertilization and cumulative knowledge development across the different theoretical streams.

We start by clarifying the meaning of the two terms that constitute the name strategic renewal. 'Renewal' relates to 'the activities a firm undertakes to alter its path dependence' (Volberda et al. 2001a, p. 160). It refers to the revitalization, redeployment or replacement of the firm's current organizational attributes (Agarwal and Helfat 2009; Teng 2007; Zahra 1996). Through renewal, organizations explore and learn entirely new ways of using their core competences and competitive approaches (Floyd and Lane 2000). 'Strategic' implies that organizations renew 'the key ideas on which they are built' (Guth and Ginsberg 1990). 'Strategic' thus refers to actions targeted at the transformation of the core capabilities associated with competitive advantage (Flier et al. 2003). Furthermore, renewal is only considered 'strategic' when it encompasses the entire company - not simply the individual or groups within the organization (Burgelman 1983b, Crossan et al. 1999; Duncan and Weiss 1979).

Based on these prior conceptualizations, we contend that there are three primary, recurrent elements that define the core of the strategic renewal concept. Strategic renewal (a) involves a transformation of the firm's core capabilities associated with competitive advantage, (b) concerns the entire organization and has implications across organizational levels and (c) is essential to break path dependence and ensure the firm's long-term survival. Based on these elements, we propose the following working definition for future strategic renewal research: 'Strategic renewal describes the process that allows organizations to alter their path dependence by transforming their strategic intent and capabilities.' As such, strategic renewal consists of distinct renewal journeys or trajectories describing the underlying patterns of action, which lead to strategic renewal over time (Kwee et al. 2011). Our definition takes a process perspective, but the focus is on those practices that ultimately contribute to successful renewal.

Strategic renewal research has been an integral part of the strategic management literature, especially in key research domains such as competitive strategy (Agarwal and Helfat 2009; Capron and Mitchell 2009; Lengnick-Hall and Inocencio-Gray 2013), corporate entrepreneurship (Guth and Ginsberg 1990; Verbeke et al. 2007; Zahra 1993) and strategy process (Chakravarthy and Doz 1992; Floyd and Wooldridge 2000; Volberda and Baden-Fuller 2003). Clarifying the conceptual boundaries should thus also help distinguish strategic renewal from related concepts in these strategic management research domains.

The 'competitive strategy' literature has discussed strategic renewal in the context of firm strategies aimed at creating competitive advantage. For example, Flier et al. (2001, p. 2168) describe strategic renewal as 'strategic actions to align organizational competencies with the environment to increase competitive advantage.' Although the strategic renewal and the competitive strategy concepts are related, strategic renewal differs from competitive strategy in at least two important ways. First, it is a much broader concept, since it refers not only to changes to the firm's competitive strategy, but also to associated changes to its business scope, core capabilities and organization design (Sharma and Chrisman 1999; Zahra 1996). Second, strategic renewal focuses on the shift from one (competitive) strategy to another, rather than exploring specific competitive strategies' antecedents, nature, and outcomes.

In 'corporate entrepreneurship' research, scholars have frequently discussed strategic renewal (Guth and Ginsberg 1990; Verbeke et al. 2007; Zahra 1996). Whereas strategic renewal is an integral part of corporate entrepreneurial efforts to revitalize existing firm businesses (Sharma and Chrisman 1999), it clearly differs from corporate venturing activities, which focus on the creation of new corporate businesses 
(Stopford and Baden-Fuller 1994; Zahra 1993). Accordingly, Guth and Ginsberg (1990) describe strategic renewal and corporate venturing as two equally important, but fundamentally different, entrepreneurial activities that occur within established corporations.

Finally, the 'strategy process' literature has repeatedly acknowledged the close connection between the 'strategic renewal' concept and the 'strategic change' concept. For example, Burgelman's (1991, p. 255) description of strategic renewal as 'major strategic change preceded by internal experimentation and selection' illustrates the close association between the two concepts. However, strategic renewal and strategic change are nevertheless distinct concepts: Strategic change functions as an umbrella concept referring to many different types of strategic changes within and across firms (Rajagopalan and Spreitzer 1997), but strategic renewal refers only to a specific type of strategic change - the transformation of the firm's current strategic intent and capabilities. Strategic renewal thus excludes other types of strategic changes, such as strategic extensions, additions or deletions (Agarwal and Helfat 2009).

\section{Key theoretical tensions}

We initially conducted a classical review that classifies prior studies according to their primary research focus, in our case the (1) antecedents, (2) processes and (3) outcomes of strategic renewal. During this review effort, we identified three key tensions in these research domains, which had emerged from strongly varying, partly contradictory perspectives. Each opposing viewpoint relies on different theoretical roots, which partly explain the differences in the assumptions and findings. Renewal scholars have concluded that multiple theoretical tensions drive strategic renewal research (Albert et al. 2015; Crossan and Berdrow 2003). We agree with these scholars' conclusion that these tensions provide an excellent starting point for reviewing the existing strategic renewal research and advancing the future research.

First, the antecedent dimension describes the sources of strategic renewal. The tension between the learning and resource perspectives on strategic renewal emerges from different theoretical explanations of how organizations renew themselves. Some scholars take an organizational learning perspective, arguing that balancing exploration and exploitation effectively is an essential element and the primary challenge of strategic renewal. Other scholars use a resource-based perspective to argue that dynamic capabilities allow firms to reconfigure their resource base and are therefore an essential driver of their strategic renewal.

Second, the process dimension refers to the actual manifestation of strategic renewal. The tension between the induced and autonomous perspectives on strategic renewal reflects the fundamental question of who initiates and implements strategic renewal within organizations. Some scholars take an upper echelons theory perspective to argue that senior managers play an essential role in initiating, enabling and controlling strategic renewal journeys. Other scholars draw on the strategy process literature to claim that lowerlevel managers and employees are important drivers of strategic renewal processes within organizations.

The final dimension captures the outcomes that firms attain through strategic renewal. The tension between the co-alignment and co-creation perspectives on strategic renewal arises from different understandings of strategic renewal's purpose. Certain scholars draw on population ecology and institutional theory to argue that firms are essentially inert and therefore align themselves reactively when contextual requirements shift. Other scholars use a co-evolutionary perspective to claim that firms continuously and proactively influence industry developments to build future competitive advantage.

We focus on these three key tensions, because their underlying theoretical perspectives are prominent and recurrent across renewal studies in different research streams. Scholars describe them as related to the main challenges and themes in the renewal literature. We are aware that these tensions are not exhaustive and do not fully capture past strategic renewal research's scope, but nevertheless represent the core of the debate and the essence of strategic renewal. Clarifying these tensions helps focus future research on strategic renewal's unique contributions. In the remainder of this section, we present each tension, uncover its theoretical foundations, discuss its commonalities and contradictions, and provide suggestions regarding the most fruitful future research paths (see Table 2).

\section{Antecedents: learning vs. resource}

The first tension emerges from alternative perspectives on how organizations renew themselves. While some scholars describe organizational learning as the essential driver of strategic renewal (Crossan et al. 1999; Jones and Macpherson 2006; Makri et al. 


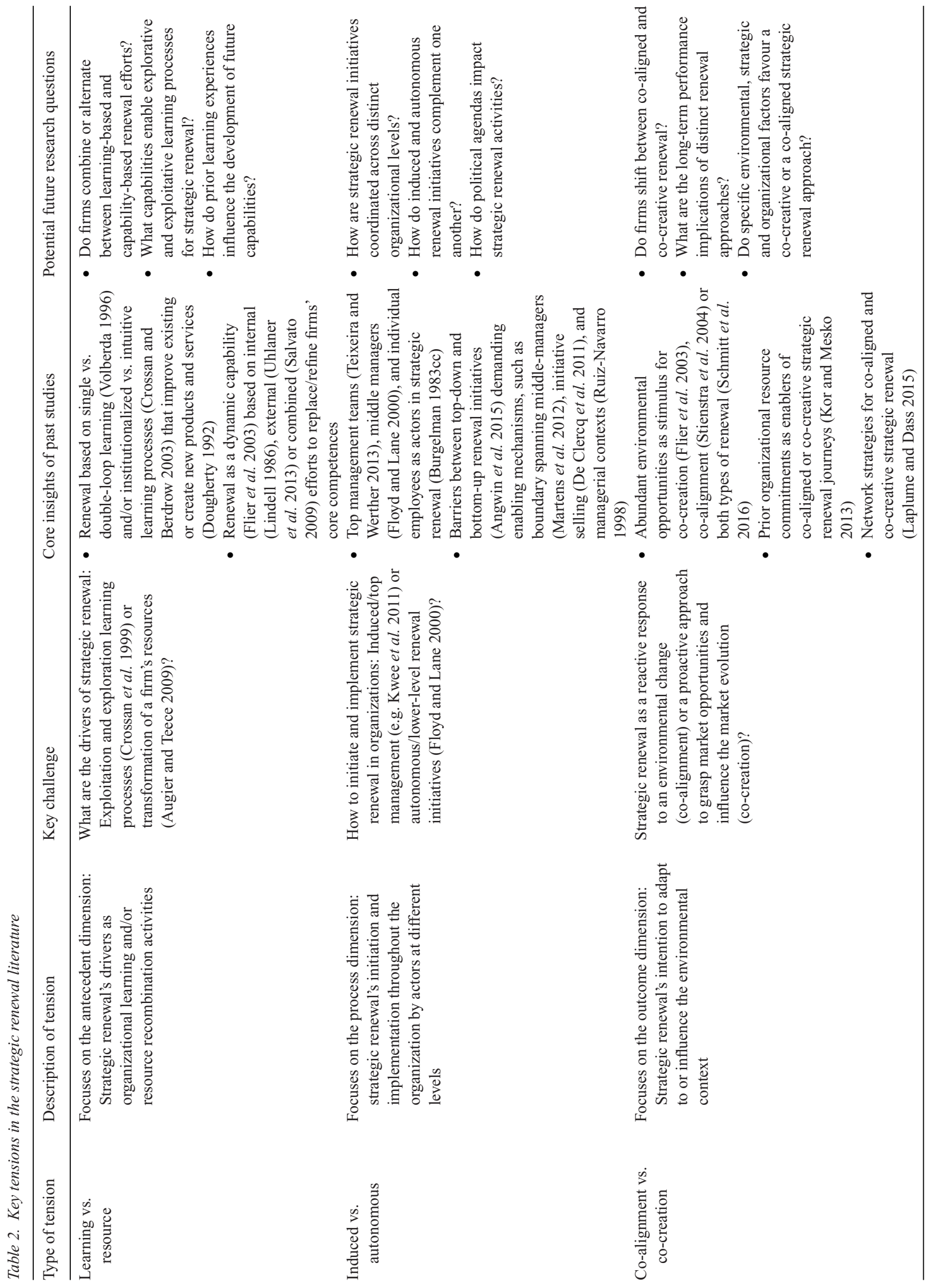


2010), others refer to dynamic capabilities and the transformation of the firm's resource base as the engine that drives strategic renewal (Agarwal and Helfat 2009; Capron and Mitchell 2009; Danneels 2002).

The learning perspective uses organizational learning theory (March, 1991) to describe the fundamental challenge of harmonizing continuity and change at the organizational level (Crossan et al. 1999). From this perspective, strategic renewal requires organizations to explore new ways while simultaneously exploiting what they have already learned (Crossan and Berdrow 2003). In the words of Volberda et al. (2001b, p. 214), 'exploitation actions are defined as renewal actions that elaborate on the current range of activities [...] (whereas) exploration actions are defined as renewal actions that add new activities to the current repertoire of the organization'. These learning categories are reflected in other dualities in the strategic renewal literature, such as product innovation vs. product exploration (Dougherty 1992; Laplume and Dass 2015), single-loop vs. double-loop learning (Bloodgood et al. 2015) and institutionalized vs. intuitive learning (Crossan and Berdrow 2003; Macpherson and Jones 2008). With strategic renewal, the challenge for organizations is to manage the tensions between the two learning types (Floyd and Lane 2000), which are contradictory and compete for scarce resources, but are also closely intertwined and mutually enabling (Crossan et al. 1999).

In contrast, the resource perspective draws on the resource-based view (Barney 1991) and the dynamic capability stream (Teece et al. 1997) to describe strategic renewal as resulting from firms' efforts to reconfigure their resource bases (Danneels 2002; Guth and Ginsberg 1990). When firms experience constraints, they strive to fill their capability gaps by modifying their resource bases (Capron and Mitchell 2009). Over time, the firm develops dynamic capabilities that it uses to undertake specific forms of strategic renewal (Agarwal and Helfat 2009). For example, strategic renewal research has described strategic renewal capabilities associated with development projects (Bowen et al. 1994; Danneels 2002), inter-firm collaborations (Smart et al. 2007), internationalization strategies (Blomkvist et al. 2010) and new product design initiatives (Ravasi and Lojacono 2005). Furthermore, scholars have argued that firms can draw on internal resources (Lindell 1986), external resources (Uhlaner et al. 2013) and combinations of the two (Salvato 2009) when developing strategic renewal capabilities. With strategic renewal, the chal- lenge for organizations is to reconfigure their resource bases in ways that enable them to develop capabilities (Agarwal and Helfat 2009).

Both perspectives and their theoretical insights have coexisted for long in the strategic renewal literature, but with very little cross-fertilization. There are a few points of convergence. For example, scholars from both the learning (Brusoni and Rosenkranz 2014; Ferguson-Amores et al. 2005) and the resource perspective (Teixeira and Werther 2013) have stressed the importance of organizational culture and identity for strategic renewal. However, there are many more points of divergence. For example, the learning perspective has almost exclusively focused on internal renewal (Albert et al. 2015), whereas the resource perspective has stressed the importance of combining internal and external renewal to widen access to critical resources (Bruton et al. 2007; Smart et al. 2007). Moreover, the learning perspective stresses lowerlevel actors' role in strategic renewal (Tippmann et al. 2014; Uhlaner et al. 2013), whereas the resource perspective focuses on senior executives (Capron and Mitchell 2009; Kor and Mesko 2013). The learning perspective also tends to stress the inherently disruptive, dynamic and recursive nature of strategic renewal (Bloodgood et al. 2015). Conversely, the resource perspective puts greater emphasis on stability and repetition's importance for the institutionalization of renewal activities (Agarwal and Helfat 2009).

Strategic renewal scholars have used these lines of divergence to propose a contingency perspective. Some have argued that the resource perspective is particularly insightful in the emergent economies context (Bruton et al. 2007; Li and Kozhikode 2008) in which the early creation of idiosyncratic capabilities can help firms set industry standards and dominate emerging markets. Others have argued that the resource perspective is equally appropriate for mature market contexts where established organizations need to challenge routines, mobilize resources and reconstruct capabilities (Ruiz-Navarro 1998; Sosa 2011). In contrast, the learning perspective proponents generally describe renewal processes in multi-business firms facing multiple environments (Burgers et al. 2009). In these multi-business contexts, balancing exploratory and exploitative learning processes allows for accommodating multiple, partly contradictory contextual requirements (Brusoni and Rosenkranz 2014).

While these contingency perspectives are certainly insightful, we fear that they may overstate the differences between the learning and resource perspectives 
on strategic renewal. Crossan and Berdrow (2003) acknowledge that organizational learning is a means to develop valuable firm capabilities. In the broader resource-based literature, scholars have explored how learning contributes to the emergence of dynamic capabilities (Zollo and Winter 2002). The broader organizational learning literature has described how different exploration-exploitation combinations draw on specific sets of dynamic capabilities to be effective (Birkinshaw et al. 2016). We therefore encourage future research that builds theoretical bridges across the learning and resource perspectives on strategic renewal. Specific capabilities that enable explorative and exploitative learning processes may drive strategic renewal. Furthermore, these learning processes may contribute to the further refinement and institutionalization of capabilities (Agarwal and Helfat 2009) but they may also help challenge emerging routines and reconfigure resources and develop new capabilities (Ruiz-Navarro 1998).

Exploring these issues in future research may motivate researchers to rethink some of the extant research's implicit assumptions. First, past renewal research has generally linked successful renewal activities to the allocation of resources to learning activities (Crossan and Berdrow 2003) or to the development of capabilities (Sosa 2011). More generally, Lewin and Volberda (1999) have argued that renewal journeys are determined primarily by the availability of organizational slack and the strategic intent to allocate it to renewal activities. However, this emphasis on resource availability fails to acknowledge strategic renewal attempts that succeed despite resource constraints. Some scholars (Basu and Wadhwa 2013; Jones and Macpherson 2006) have acknowledged the possibility of bypassing resource limitations by creating venture units or inter-organizational collaborations. Schmitt et al. (2016) highlight strategic renewal efforts based on 'resource-light' learning approaches, such as entrepreneurial bricolage (Baker and Nelson 2005). In this context, it could be promising if future research were to identify and compare renewal approaches where abundant resources enable learning and renewal approaches where learning occurs in spite of resource scarcity conditions.

Second, past research has warned that the reliance on well-established routines in strategic renewal impedes experimentation and learning (Angwin et al. 2015; Li and Kozhikode 2008). Consequently, organizational members tend to limit their knowledge search to a few well-known sources, which leads to increasingly specialized knowledge domains
(Tippmann et al. 2014) and constrains the ability to develop new capabilities (Capron and Mitchell 2009). However, broader organization theory research also suggests that routines can foster knowledge sharing (Baum and Wally 2003), provide guidance for nonroutine activities (Dougherty 2006) and eliminate uncertainties to create a climate of psychological safety (Bunderson and Boumgarden 2010), all of which support exploration and exploitation (Farjoun 2010) and capability development (Agarwal and Helfat 2009). These combined insights lead to interesting questions regarding the roles of routinized and non-routinized behaviours for organizational learning and capability building in the strategic renewal context.

\section{Processes: induced vs. autonomous}

The tension between induced and autonomous strategic renewal reflects the fundamental question of who initiates and drives strategic renewal initiatives. While some scholars describe how senior executives design and implement strategic renewal initiatives (Kwee et al. 2011; Mitchell et al. 2009; Whitney 1996), others present managers and employees at lower levels of the organization initiating strategic renewal initiatives (Burgelman 1983a, Floyd and Lane 2000; Pappas and Wooldridge 2007).

The induced perspective builds on upper echelons theory (Hambrick and Mason 1984) and its central premise that executives' experiences, values and personalities influence their interpretations of the situations they face and, in turn, affect their choices (Hambrick 2007). As a consequence, strategy and performance outcomes depend, at least in part, on the top management team composition and processes. Building on these theoretical concepts, scholars have repeatedly stressed the importance of senior managers for strategic renewal (Barr et al. 1992; Buyl et al. 2011; McGrath and MacMillan 2009). Senior executives' entrepreneurial culture is conducive for initiating renewal initiatives and implementing them throughout the organization (Teixeira and Werther 2013). How senior managers notice, interpret and formulate strategic renewal choices shape strategic renewal activities (Eggers and Kaplan 2009; Hurst et al. 1989; Spender and Grinyer 1995). Strategic renewal efforts are therefore subject to managerial mental models that justify certain activities within the organization (Barr et al. 1992).

However, upper echelons research also has a long tradition of investigating senior executives' decisionmaking limitations and biases (Hambrick 2007). 
Past strategic renewal research shows that top-downdriven renewal initiatives can create institutionalized contexts that determine acceptable and unacceptable behaviours and processes, effectively creating barriers to bottom-up strategic renewal initiatives (Verbeke et al. 2007). Senior executives therefore risk reinforcing their own, centralized renewal orientation (Lindell 1986), while stifling lower-level managers and employees' creative abilities in the process. Since lower-level actors are generally more closely involved with the firm's customers and competitors, not considering their input may decelerate, or even cause the failure of, the firm's strategic renewal efforts.

In contrast, the autonomous perspective draws primarily on the strategy process literature (Pettigrew 1992; Wooldridge and Floyd 1990) to argue that strategic renewal in organizations is not necessarily a top-down process. Burgelman (1983a,b,c) describes strategic renewal as the product of autonomous behaviour initiated outside the top management. Frontline managers frequently take initiative to pursue new ideas (Volberda et al. 2001a) and to sell issues to their superiors (De Clercq et al. 2011). These managers can therefore play an active role in nurturing and advocating strategic renewal processes (Pappas and Wooldridge 2007). Bottom-up knowledge inflows provide higher-level managers with an increased understanding of changes regarding technologies, products and markets, which can trigger them to revise strategic decisions (Floyd and Lane 2000). From this perspective, strategic renewal relies on entrepreneurial participants at the product/market level who conceive new business opportunities and pursue them by mobilizing corporate resources (Burgelman 1983c).

However, the autonomous perspective also acknowledges the limitations of a bottom-up approach to strategic renewal. Floyd and Lane (2000) argue that organizations relying primarily on bottom-up renewal initiatives bear the risk of depending on uncoordinated efforts that may ultimately fail to gain traction across the organization as a whole. For example, lower-level management may exaggerate the importance of local errors and become over-responsive to fads and fashions (Floyd and Wooldridge 1997). Continuous adjustments may waste resources on 'noise' in environmental signals, which may subsequently create an over-adaptive organization that cannot maintain a sense of identity and continuity over time (Volberda and Lewin 2003). This could even create a vicious circle that results in a firm burdened by potentially serious problems, such as authority conflicts, unclear responsibilities, inadequate controls, lack of direction and, consequently, a greater propensity for chaos and inefficiency (Volberda 1998).

Previous strategic renewal literature largely explored the induced initiatives and autonomous initiatives separately. While scholars repeatedly acknowledge the tensions between these two types of renewal initiatives, the literature still lacks a more integrative perspective. As a rare exception, Volberda and Lewin (2003) argue in favour of a balanced approach of induced and autonomous renewal initiatives. Moreover, De Clercq et al. (2011) have emphasized initiative selling's role as a possible solution to managing the tensions between the two approaches. Lower-level managers use such bottom-up efforts as their contribution to the top management decision process. However, these studies do not address (a) how induced and autonomous strategic renewal initiatives complement one another, (b) whether these two types of initiatives describe two different phases within the same strategic renewal process, and (c) how organizational actors can coordinate top-down and bottom-up strategic renewal initiatives.

We encourage future research to address the 'hierarchical disconnect' that tensions between organizations and their members cause (Angwin et al. 2015). Strategic renewal activities that one hierarchical level (e.g. senior executives) drives may create political tensions, suffer from a lack of expertise, and face antipathy and/or contrary personal agendas at other hierarchical levels (e.g. middle managers). Consequently, relationships and exchanges across levels may be decisive for strategic renewal efforts. However, we know very little about these relationships. While previous literature hailed middle managers as boundary-spanners promoting strategic renewal throughout the organization (Floyd and Lane 2000; Pappas and Wooldridge 2007; Tippmann et al. 2014), renewal research should also explore how organizational, behavioural and cognitive factors may influence middle-managers' success or failure in this challenging role.

Addressing these issues may require rethinking some of strategic renewal research's implicit assumptions. First, past research has often argued in favour of corporate control systems (Simons 1994), formalized processes and centralized reward systems as tools for managing strategic renewal (De Clercq et al. 2011). However, we also know that autonomous strategic initiatives require considerable flexibility and leeway for team-based efforts (Burgers et al. 2009). There 
is room for fresh perspectives on how organizational structures, processes and systems should be designed to enable both induced and autonomous renewal initiatives.

Second, we have to move away from an overly mechanistic understanding of how reward and incentive systems influence strategic renewal behaviour. Lechner and Floyd (2012) show that past strategic renewal initiatives' performance influences subsequent initiatives' formulation and implementation. This could mean that middle managers who successfully (or unsuccessfully) promoted autonomous renewal efforts in the past, may be more (or less) inclined to support such efforts further. In other words, more longitudinal perspectives could provide a better understanding of how past experiences with induced and autonomous renewal initiatives influence the organization's ability and motivation to engage in more. Examining transitions between induced and autonomous initiatives (or vice versa) could be particularly promising to uncover the drivers of and interrelations between the two types of strategic renewal initiatives.

\section{Outcomes: co-alignment vs. co-creation}

According to prior renewal research, firms strive for two alternative strategic renewal outcomes: coalignment and co-creation. Drawing on Huff et al.'s (1992) model of stress and inertia, the co-alignment approach describes strategic renewal's purpose as the re-creation of fit between the firm and its environment. According to this perspective, firms are generally inert and only engage in strategic renewal to reduce the level of organizational stress that a misalignment with the changing environmental conditions causes. Conversely, the co-creation approach suggests that firms constantly engage in strategic renewal to remain agile (Agarwal and Helfat 2009; Ravasi and Lojacono 2005; Volberda et al. 2001a). Rather than responding to environmental changes, co-creation aims to proactively generate new opportunities and influence the market's evolution (Martens et al. 2012; Peltola 2012).

The co-alignment perspective has its theoretical roots in population ecology and institutional theory. According to population ecology, major changes to an organization's core competences are similar 'to creating a new organization' (Hannan and Freeman 1984, p. 159), thereby re-creating a liability of newness (Stinchcombe 1965), which increases the probability of organizational failure (Hannan and Freeman
1989). Building on these arguments, renewal scholars have argued that organizations tend to reinforce their current activity systems rather than engaging in an evolutionary process of strategic renewal (Albert et al. 2015). Moreover, scholars have used institutional theory arguments about mimetic isomorphism and bandwagon pressures (Flier et al. 2003; Kwee et al. 2011) to explain why firms tend to adopt renewal initiatives similar to those already in use within their industry, rather than developing their own, firm-specific initiatives (Capron and Mitchell 2009; Volberda et al. 2001b). The consequence of such behaviour is that the repeated changes in the environment cause the firm's activity system to become increasingly misaligned, which eventually leads to discontinuous strategic renewal when firm survival is threatened (Huff et al. 1992). In the co-alignment perspective, strategic renewal's outcome thus refers to the organizational (re)alignment with the altered environmental conditions (Eggers and Kaplan 2009; Huygens et al. 2001; Kim and Pennings 2009).

Conversely, from the co-creation perspective, renewal journeys do not occur in a vacuum and are unlikely to follow simple adaptation-selection logics (Flier et al. 2003). Co-evolutionary models incorporate the premise that adaptation and selection are not orthogonal forces, but are fundamentally interrelated. Strategic renewal emerges from recursive interactions between a firm's strategy and its environment (Volberda and Lewin 2003). Borrowing from complexity theory (McKelvey 2001; Stacey 1995), proponents of the co-evolutionary perspective argue that recursive interactions make organizations lose their equilibrium and enable continuous strategic renewal (Albert et al. 2015; Volberda and Lewin 2003). Continuous attention to and managerial intentionality regarding strategic renewal characterize such co-evolving organizations (Huygens et al. 2001). From the co-creation perspective, strategic renewal's outcome thus refers to proactively setting industry standards and influencing industry evolution (Eggers and Kaplan 2009; Kim and Pennings 2009).

While scholars at first argued that the distinction between the co-alignment and co-creation approaches may be nothing more than a question of how organizational members construct their reality socially (e.g. Barr et al. 1992), the subsequent renewal literature has reinforced the dichotomy between the two concepts. Scholars have generally argued that whether firms opt for one or the other approach depends on their environmental conditions (Volberda et al. 2001b). For example, firms facing abundant environmental 
opportunities may adopt co-creation strategies, since they are more concerned with capitalizing on external opportunities and less concerned with preserving internal resources (Flier et al. 2003). In contrast, Stienstra et al. (2004) have suggested that high environmental dynamism may force organizations to adopt a co-alignment approach. Further, Schmitt et al. (2016) have argued that firms facing environmental scarcity situations choose either co-alignment or co-creation approaches, depending on the managerial assessment of the severity and duration of the decline.

It is doubtful whether such contingency perspectives are sufficient to explain the roles of co-alignment and co-creation in strategic renewal. Firms tend to face complex environments with multiple, simultaneously occurring dynamics. For example, prior studies found that market saturation (Kim and Pennings 2009) and technology shifts (Knott and Posen 2009) are both important triggers of renewal activities. However, technology shifts often occur in industries characterized by market saturation. Furthermore, these technology shifts generally increase the levels of environmental dynamism and competitive rivalry, two additional triggers of strategic renewal (Huygens et al. 2001). Many firms may thus face complex environmental situations that call for co-alignment and cocreation approaches to strategic renewal (Floyd and Wooldridge 1997). Furthermore, firms may experience shifts in their environmental conditions that motivate them to transition between co-alignment and co-creation approaches. Future research should thus take a broader perspective to explore how the two approaches to strategic renewal are interrelated and whether firms alternate between them over time.

This broader perspective may require strategic renewal scholars to rethink some of the previous literature's assumptions. First, the tension between coalignment and co-creation approaches suggests a more complex interrelationship between a firm's internal and external environments. For example, Kor and Mesko (2013) find that prior firm choices regarding its competitive strategy, resource deployment and investment behaviour affect its future strategic renewal activities. Future research may thus have to explore the firm's internal and external environments simultaneously as well as the interrelations between them to understand the strategic renewal activities they cause. Second, there is increasing recognition that opening the firm boundaries can support strategic renewal journeys (Laplume and Dass 2015). For instance, open innovation strategies and interorganizational relationships may help firms anticipate events, trends and changes in the market (which enables co-creation), but also help them adapt to such changes once these materialize in their industry environments (which enables co-alignment).

\section{Synthesis and future research}

This review of 33 years of strategic renewal research has allowed us to categorize and analyse prior contributions, but also to identify important gaps and shortcomings. Prior strategic renewal studies not only drew on a variety of theoretical foundations, but also had a tendency to focus on selected dimensions of the strategic renewal construct. While this trend has contributed to a vibrant research field, it has also led to polarizing perspectives that inhibit scholarly discourse. The tensions between these perspectives bias theorists against opposing explanations, and they run the risk of developing parochial theories (Bouchikhi 1998).

Poole and Van de Ven $(1989$, p. 563) propose that researchers facing such polarizing perspectives in a research domain should 'look for theoretical tensions or oppositions and use them to stimulate the development of more encompassing theories'. In our review, we have identified three theoretical tensions in previous strategic renewal research. We have discussed their theoretical foundations, as well as the complementarities and contradictions in their findings and contributions. In this final section, we conclude our efforts by proposing our future research agenda for greater synthesis and integration across the polarizing perspectives.

Integration across polarizing perspectives requires a paradox lens that allows scholars to embrace theoretical views deemed logical in isolation, yet conflicting and problematic when juxtaposed (Schad et al. 2016). Moreover, a paradox lens helps scholars explore greater theoretical and organizational complexity and thus extends the scope, relevance and creativity of their research (Lewis and Grimes 1999). Taking a paradox perspective, we suggest that future strategic renewal research encourages 'both/and' perspectives, explores temporal dynamics, and considers the spatial dimensions to better comprehend and bridge theoretical tensions.

First, we encourage 'both/and' rather than 'either/ or' perspectives on strategic renewal. Past strategic renewal studies have generally taken an 'either/or' perspective focused on identifying contingency factors that drive firms' choices between alternative 
renewal approaches. For example, scholars have argued that whether the learning or resource, induced or autonomous, and co-alignment or co-creation perspectives on strategic renewal have greater explanatory power depends on the specific contextual conditions (Ruiz-Navarro 1998; Volberda and Lewin 2003; Volberda et al. 2001b). Lewis and Smith (2014) positioned the paradox perspective ('both/and') as a timely alternative to the contingency theory ('either/ or') approach.

Such a 'both/and' perspective may be useful to integrate the many contrary arguments in prior research. For example, certain scholars argue that firm size leads to organizational inertia, which restricts firms' learning during strategic renewal (Rothaermel and Deeds 2004), but others suggest that firm size means preferential access to resources, which enables strategic renewal (Basu and Wadhwa 2013). Paradox researchers suggest that taking a 'both/and' perspective (Smith and Lewis 2011) helps reconcile such contradictory arguments by exploring their interrelations. Taking a 'both/and' perspective leads to a set of potentially interesting future research questions: How do firms' learnings from prior strategic renewal experiences contribute to the development of their dynamic capabilities? How do senior executives and lower-level managers interact during strategic renewal initiatives? How can firms set new industry standards while adapting their organizations to the changing environmental conditions?

Second, we encourage scholars to explore the temporal dynamics of strategic renewal. While strategic renewal has often been defined as a process, prior empirical studies frequently took a rather static approach (Ben-Menahem et al. 2013). However, paradox scholars stress that tensions are persistent - they initiate a cyclical relationship between opposing forces (Smith and Lewis 2011). Neglecting one side of the duality may cause escalating cycles. This dynamic relationship therefore suggests a processual perspective, understanding how each element informs and defines the other (Schad et al. 2016). Future renewal research could benefit from more longitudinal study designs in order to examine the timing, sequencing and performance implications of different strategic renewal activities over time.

As Kwee et al. (2011) have argued, strategic renewal manifests itself in trajectories, which are continuous processes of multiple, different renewal activities. This evolution of the firm's strategic renewal activities is path dependent: Previous strategic renewal activities and their performance outcomes influence the firm's subsequent renewal activities (Volberda and Lewin 2003). Longer time horizons thus allow a more fine-grained understanding of 'when', 'how' and 'why' organizations adopt specific strategic renewal behaviours (Ben-Menahem et al. 2013). The following questions may guide future research on temporal dynamics: How do organizations learn to renew themselves by building and breaking routines for strategic renewal? Does the responsibility for the initiation, implementation and revision of strategic renewal initiatives shift over time? Do organizations alternate between co-alignment and co-creation approaches over time? Which factors trigger such shifts?

Third, we encourage scholars to consider the spatial dimension of strategic renewal. While previous research describes strategic renewal as an organizationlevel phenomenon, it nevertheless affects multiple levels within the organization (Lechner and Floyd 2012; Salvato 2009). Most prior studies focused on the interaction between the firm and its environment, but largely ignored intra-firm interactions across organizational levels. However, strategic renewal in large, complex firms is often less centralized, less rational and less one-dimensional than described in these studies (Floyd and Lane 2000). As prior paradox research suggests, tensions are often 'nested' across levels, and scholars should therefore prioritize multilevel inquiries that explore the micro-foundations of tensions as well as the aggregation of lower-level activities across organizational levels (Schad et al. 2016).

For example, senior executives may initiate capability-building activities, but lower-level managers may engage in learning activities related to strategic renewal. While the learning-resource tension in this example is partially nested across levels, new tensions may arise from integrating these activities across levels. Furthermore, this example suggests that the multiple tensions that prior studies explored individually - such as the learning-resource and the induced-autonomous tensions - may be more closely interrelated than previously assumed. Paradox studies stress that the multiple tensions within organizations are often interrelated (Smith and Lewis 2011). Addressing one of these tensions individually may cause ripple effects that reinforce other, related tensions. If future research were to take a broader perspective and consider the multiple tensions related to strategic renewal, this could be an important contribution to the literature. This leads us to a final set of future research questions: How do senior executives perceive, select 
and coordinate multiple strategic renewal initiatives that emerge at the lower organizational levels? What drives front-line employees and middle managers to become actively involved in strategic renewal efforts and how can senior executives build contexts that enable these lower-level actors to build internal support for their strategic renewal initiatives? How do these efforts at various organizational levels differ with respect to the antecedents and outcomes of strategic renewal?

\section{Conclusion}

Virtually every organization faces the dilemma of either maintaining continuity or engaging in strategic renewal. Continuity ensures reliability and cohesion, but strategic renewal is equally important to enable innovation and evolution. Consequently, research on strategic renewal can help researchers and practitioners clarify the processes underlying firms' long-term survival and prosperity. Because it deals with such important issues, strategic renewal has become a vibrant field of study over the last three decades. While previous studies made significant contributions towards a better understanding of strategic renewal's complex nature, our review also indicates the need for further conceptual work to integrate these contributions from a wide variety of different theoretical perspectives and research contexts. The approach we took in this review was to identify and discuss the key theoretical tensions across these studies. By integrating the various strands of the literature, we help scholars understand the current state of play in this field and provide useful guidance on key themes for future research. We expect strategic renewal research to continue its accelerating growth, thus contributing to an even richer, more complete and, ultimately, more realistic understanding of how established firms break their path dependence and transform themselves to ensure their long-term prosperity.

\section{References}

Agarwal, R. and Helfat, C.E. (2009). Strategic renewal of organizations. Organization Science, 20, pp. 281-293.

Albert, D., Kreutzer, M. and Lechner, C. (2015). Resolving the paradox of interdependency and strategic renewal in activity systems. Academy of Management Review, 40, pp. 210-234.

Angwin, D.N., Paroutis, S. and Connell, R. (2015). Why good things don't happen: the micro-foundations of routines in the M\&A process. Journal of Business Research, 68 , pp. 1367-1381.

Augier, M. and Teece, D.J. (2009). Dynamic capabilities and the role of managers in business strategy and economic performance. Organization Science, 20, pp. 410-421.

Baker, T. and Nelson, R.E. (2005). Creating something from nothing: resource construction through entrepreneurial bricolage. Administrative Science Quarterly, 50, pp. 329366.

Barney, J.B. (1991). Firm resources and sustained competitive advantage. Journal of Management, 17, pp. 94-120.

Barr, P.S., Stimpert, J.L. and Huff, A.S. (1992). Cognitive change, strategic action, and organizational renewal. Strategic Management Journal, 13, pp. 15-36.

Basu, S. and Wadhwa, A. (2013). External venturing and discontinuous strategic renewal: an options perspective. Journal of Product Innovation Management, 30, pp. 956975.

Baum, J.R. and Wally, S. (2003). Strategic decision speed and firm performance. Strategic Management Journal, 24, pp. 1107-1129.

Ben-Menahem, S.M., Kwee, Z., Volberda, H. and Van Den Bosch, F.a.J. (2013). Strategic renewal over time: the enabling role of potential absorptive capacity in aligning internal and external rates of change. Long Range Planning, 46, pp. 216-235.

Birkinshaw, J., Zimmermann, A. and Raisch, S. (2016). How do firms adapt to discontinuous change? California Management Review, 58, pp. 36-58.

Blomkvist, K., Kappen, P. and Zander, I. (2010). Quo vadis? The entry into new technologies in advanced foreign subsidiaries of the multinational enterprise. Journal of International Business Studies, 41, pp. 1525-1549.

Bloodgood, J.M., Hornsby, J.S., Burkemper, A.C. and Sarooghi, H. (2015). A system dynamics perspective of corporate entrepreneurship. Small Business Economics, 45, pp. 383-402.

Bouchikhi, H. (1998). Living with and building on complexity: a constructivist perspective on organizations. Organization, 5, pp. 217-232.

Bowen, H.K., Clark, K.B., Holloway, C.A. and Wheelwright, S.C. (1994). Regaining the lead in manufacturing. Development-projects: the engine of renewal. Harvard Business Review, 72, pp. 108-109.

Brusoni, S. and Rosenkranz, N.A. (2014). Reading between the lines: learning as a process between organizational context and individuals' proclivities. European Management Journal, 32, pp. 147-154.

Bruton, C.D., Dess, G.G. and Janney, J.J. (2007). Knowledge management in technology-focused firms in emerging economies: caveats on capabilities, networks, and real options. Asia Pacific Journal of Management, 24, pp. 115130.

Bunderson, J.S. and Boumgarden, P. (2010). Structure and learning in self-managed teams: why 'bureaucratic' teams 
can be better learners. Organization Science, 21, pp. 609624.

Burgelman, R.A. (1983a). Corporate entrepreneurship and strategic management: insights from a process study. Management Science, 29, pp. 1349-1364.

Burgelman, R.A. (1983b). A model of the interaction of strategic behavior, corporate context, and the concept of strategy. Academy of Management Review, 8, pp. 61-70.

Burgelman, R.A. (1983c). A process model of internal corporate venturing in the diversified major firm. Administrative Science Quarterly, 28, pp. 223-244.

Burgelman, R.A. (1991). Intraorganizational ecology of strategy making and organizational adaptation: theory and field research. Organization Science, 2, pp. 239-262.

Burgers, J.H., Jansen, J.J.P., Van Den Bosch, F.a.J. and Volberda, H. (2009). Structural differentiation and corporate venturing: the moderating role of formal and informal integration mechanisms. Journal of Business Venturing, 24, pp. 206-220.

Buyl, T., Boone, C. and Matthyssens, P. (2011). Upper echelons research and managerial cognition. Strategic Organization, 9, pp. 240-246.

Capron, L. and Mitchell, W. (2009). Selection capability: how capability gaps and internal social frictions affect internal and external strategic renewal. Organization Science, 20, pp. 294-312.

Chakravarthy, B. and Gargiulo, M. (1998). Maintaining leadership legitimacy in the transition to new organizational forms. Journal of Management Studies, 35, pp. 437-456.

Chakravarthy, B.S. (1984). Strategic self-renewal: a planning framework for today. Academy of Management Review, $\mathbf{9}$, pp. 536-547.

Chakravarthy, B.S. and Doz, Y. (1992). Strategy process research: focus on corporate self-renewal. Strategic Management Journal, 13, pp. 5-14.

Cho, T.S. and Hambrick, D.C. (2006). Attention as the mediator between top management team characteristics and strategic change: the case of the airline deregulation. Organization Science, 17, pp. 453-469.

Crossan, M.M. and Berdrow, I. (2003). Organizational learning and strategic renewal. Strategic Management Journal, 24, pp. 1087-1105.

Crossan, M.M., Lane, H.W. and White, R.E. (1999). An organizational learning framework: from intuition to institution. Academy of Management Review, 24, pp. 552-537.

Danneels, E. (2002). The dynamics of product innovation and firm competences. Strategic Management Journal, 23, pp. 1095-1121.

De Clercq, D., Castaner, X. and Belausteguigoitia, I. (2011). Entrepreneurial initiative selling within organizations: towards a more comprehensive motivational framework. Journal of Management Studies, 48, pp. 1269-1290.

Denyer, D. and Tranfield, D. (2008). Producing a systematic review. In Buchanan, D. (ed.), The Sage Handbook of Organization Research Methods. London: Sage, pp. 671689.
Dougherty, D. (1992). A practice-centered model of organizational renewal through product innovation. Strategic Management Journal, 13, pp. 77-92.

Dougherty, D. (2006). Organizing for innovation in the $21 \mathrm{st}$ century. In Clegg, S.R., Hardy, C., Lawrence, T. and Nord, W.R. (eds), The Sage Handbook of Organization Studies. London: Sage, pp. 598-617.

Duncan, R.B. and Weiss, A. (1979). Organizational learning: implications for organizational design. Research in Organizational Behavior, 1, pp. 75-124.

Eggers, J.P. and Kaplan, S. (2009). Cognition and renewal: comparing $\mathrm{CEO}$ and organizational effects on incumbent adaptation to technical change. Organization Science, 20, pp. 461-477.

Farjoun, M. (2010). Beyond dualism: stability and change as a duality. Academy of Management Review, 35, pp. 202225.

Ferguson-Amores, M., Garcia-Rodriguez, M. and RuizNavarro, J. (2005). Strategies of renewal - The transition from 'Total Quality Management' to the 'Learning Organization'. Management Learning, 36, pp. 149-180.

Flier, B., Van Den Bosch, F.a.J., Volberda, H.W., Carnevale, C.A., Tomkin, N., Melin, L., Quelin, B.V. and Kriger, M.P. (2001). The changing landscape of the European financial services sector. Long Range Planning, 34, pp. 179207.

Flier, B., Van Den Bosch, F.a.J. and Volberda, H. (2003). Coevolution in the strategic renewal behaviour of British, Dutch and French financial incumbents: interaction of environmental selection, institutional effects, and managerial intentionality. Journal of Management Studies, 40, pp. 2163-2187.

Floyd, S.W. and Lane, P.J. (2000). Strategizing throughout the organization: managing role conflict in strategic renewal. Academy of Management Review, 25, pp. 154-177.

Floyd, S.W. and Wooldridge, B. (1997). Middle management's strategic influence and organizational performance. Journal of Management Studies, 34, pp. 465-485.

Floyd, S.W. and Wooldridge, B. (2000). Building Strategy from the Middle: Reconceptualizing Strategy Process. London: Sage.

Guth, W.D. and Ginsberg, A. (1990). Guest editors' introduction: corporate entrepreneurship. Strategic Management Journal, 11, pp. 5-15.

Haggerty, P.E. (1969). Corporate self renewal. Long Range Planning, 1, pp. 9-15.

Hambrick, D.C. (2007). Upper echelons theory: an update. Academy of Management Review, 32, pp. 334-343.

Hambrick, D.C. and Mason, P.A. (1984). Upper echelon: the organization as a reflection of its top managers. Academy of Management Review, 9, pp. 193-206.

Hannan, M.T. and Freeman, J. (1984). Structural inertia and organizational change. American Sociological Review, 49, pp. 149-164.

Hannan, M.T. and Freeman, J. (1989). Organizational Ecology. Cambridge, MA: Harvard University Press. 
Huff, J.O., Huff, A.S. and Thomas, H. (1992). Strategic renewal and the interaction of cumulative stress and inertia. Strategic Management Journal, 13, pp. 55-75.

Hurst, D.K., Rush, J.C. and White, R.E. (1989). Top management teams and organizational renewal. Strategic Management Journal, 10, pp. 87-105.

Huygens, M., Baden-Fuller, C., Van Den Bosch, F.a.J. and Volberda, H. (2001). Co-evolution of firm capabilities and industry competition: investigating the music industry, 1877-1997. Organization Studies, 22, pp. 9711011.

Jaw, B.S. and Liu, W.N. (2003). Promoting organizational learning and self-renewal in Taiwanese companies: the role of HRM. Human Resource Management, 42, pp. 223241.

Jones, O. and Macpherson, A. (2006). Inter-organizational learning and strategic renewal in SMEs. Long Range Planning, 39, pp. 155-175.

Kim, H.E. and Pennings, J.M. (2009). Innovation and strategic renewal in mature markets: a study of the tennis racket industry. Organization Science, 20, pp. 368-383.

Knott, A.M. and Posen, H.E. (2009). Firm R\&D behavior and evolving technology in established industries. Organization Science, 20, pp. 352-367.

Kor, Y.Y. and Mesko, A. (2013). Dynamic managerial capabilities: configuration and orchestration of top executives' capabilities and the firm's dominant logic. Strategic Management Journal, 34, pp. 233-244.

Kwee, Z., Van Den Bosch, F.a.J. and Volberda, H. (2011). The influence of top management team's corporate governance orientation on strategic renewal trajectories: a longitudinal analysis of Royal Dutch Shell plc, 1907-2004. Journal of Management Studies, 48, pp. 984-1014.

Laplume, A.O. and Dass, P. (2015). Outstreaming for ambidexterity: evolving a firm's core business from components to systems by serving internal and external customers. Long Range Planning, 48, pp. 135-150.

Lechner, C. and Floyd, S.W. (2012). Group influence activities and the performance of strategic initiatives. Strategic Management Journal, 33, pp. 478-495.

Lee, R. (2009). Social capital and business management: setting a research agenda. International Journal of Management Reviews, 11, pp. 247-273.

Lengnick-Hall, C.A. and Inocencio-Gray, J.L. (2013). Institutionalized organizational learning and strategic renewal: the benefits and liabilities of prevailing wisdom. Journal of Leadership and Organizational Studies, 20, pp. 420-435.

Lewin, A.Y. and Volberda, H.W. (1999). Prolegomena on coevolution: a framework for research on strategy and new organization forms. Organization Science, 10, pp. 519534.

Lewis, M. W. and Grimes, A. J. (1999). Metatriangulation: building theory from multiple paradigms. Academy of Management Review, 24, pp. 672-690.

Lewis, M. W. and Smith, W. K. (2014). Paradox as a metatheoretical perspective: sharpening the focus and widening the scope. Journal of Applied Behavioral Science, 50, pp. 127-149.

Li, J. and Kozhikode, R.K. (2008). Knowledge management and innovation strategy: the challenge for latecomers in emerging economies. Asia Pacific Journal of Management, 25, pp. 429-450.

Lindell, M. (1986). Renewal strategies in large high-tech companies - The European approach. Technovation, 5, pp. 183-199.

Macpherson, A. and Jones, O. (2008). Object-mediated learning and strategic renewal in a mature organization. Management Learning, 39, pp. 177-201.

Macpherson, A. and Jones, O. (2010). Editorial: strategies for the development of international journal of management reviews. International Journal of Management Reviews, 12, pp. 107-113.

Makri, M., Hitt, M.A. and Lane, P.J. (2010). Complementary technologies, knowledge relatedness, and invention outcomes in high technology mergers and acquisitions. Strategic Management Journal, 31, pp. 602-628.

March, J.G. (1991). Exploration and exploitation in organizational learning. Organization Science, 2, pp. 7187.

Martens, R., Matthyssens, P. and Vandenbempt, K. (2012). Market strategy renewal as a dynamic incremental process. Journal of Business Research, 65, pp. 720-728.

McGrath, R.G. and Macmillan, I.C. (2009). How to rethink your business during uncertainty. MIT Sloan Management Review, 50, pp. 25-30.

McKelvey, B. (2001). What is complexity science? It is really order-creation science. Emergence, 3, pp. 137-157.

Miles, M.P., Paul, C.W. and Wilhite, A. (2003). Modeling corporate entrepreneurship as rent-seeking competition. Technovation, 23, pp. 393-400.

Mitchell, J.R., Hart, T.A., Valcea, S. and Townsend, D.M. (2009). Becoming the boss: discretion and postsuccession success in family firms. Entrepreneurship Theory and Practice, 33, pp. 1201-1218.

Pappas, J.M. and Wooldridge, B. (2007). Middle managers' divergent strategic activity: an investigation of multiple measures of network centrality. Journal of Management Studies, 44, pp. 323-341.

Peltola, S. (2012). Can an old firm learn new tricks? A corporate entrepreneurship approach to organizational renewal. Business Horizons, 55, pp. 43-51.

Pettigrew, A.M. (1992). The character and significance of strategy process research. Strategic Management Journal, 13, pp. 5-16.

Poole, M. S. and Van de Ven, A. H. (1989). Using paradox to build management and organization theories. Academy of Management Review, 14, pp. 562-578.

Prashantham, S. (2008). New venture internationalization as strategic renewal. European Management Journal, 26, pp. 378-387.

Rajagopalan, N. and Spreitzer, G. (1997). Toward a theory of strategic change: a multi-lens perspective and integrative 
framework. Academy of Management Review, 22, pp. 4879.

Ravasi, D. and Lojacono, G. (2005). Managing design and designers for strategic renewal. Long Range Planning, 38, pp. 51-77.

Rothaermel, F.T. and Deeds, D.L. (2004). Exploration and exploitation alliances in biotechnology: a system of new product development. Strategic Management Journal, 25, pp. 201-221.

Ruiz-Navarro, J. (1998). Turnaround and renewal in a Spanish shipyard. Long Range Planning, 31, pp. 51-59.

Salvato, C. (2009). Capabilities unveiled: the role of ordinary activities in the evolution of product development processes. Organization Science, 20, pp. 384-409.

Schad J., Lewis, M.W., Raisch, S. and Smith, W.K. (2016). Paradox research in management science: looking back to move forward. Academy of Management Annals, 10, pp. 5-64.

Schmitt, A., Barker, V.L., Raisch, S. and Whetten, D. (2016). Strategic renewal in times of environmental scarcity. Long Range Planning, 49, pp. 361-376.

Sharma, P. and Chrisman, J.J. (1999). Toward a reconciliation of the definitional issues in the field of corporate entrepreneurship. Entrepreneurship: Theory \& Practice, 23, pp. 11-27.

Simons, R. (1994). How new top managers use control systems as levers of strategic renewal. Strategic Management Journal, 15, pp. 169-189.

Smart, P., Bessant, J. and Gupta, A. (2007). Towards technological rules for designing innovation networks: a dynamic capabilities view. International Journal of Operations \& Production Management, 27, pp. 1069-1092.

Smith, W.K. and Lewis, M.W. (2011). Toward a theory of paradox: a dynamic equilibrium model of organizing. Academy of Management Review, 36, pp. 381403.

Smits, H.N.J. and Groeneveld, J.M. (2001). Reflections on strategic renewal at Rabobank - A CEO perspective. Long Range Planning, 34, pp. 249-258.

Sosa, M.L. (2011). From old competence destruction to new competence access: evidence from the comparison of two discontinuities in anticancer drug discovery. Organization Science, 22, pp. 1500-1516.

Spender, J.C. and Grinyer, P.H. (1995). Organizational renewal: top managements role in a loosely-coupled system. Human Relations, 48, pp. 909-926.

Stacey, R.D. (1995). The science of complexity: an alternative perspective for strategic change processes. Strategic Management Journal, 16, pp. 477-495.

Stadler, C., Rajwani, T. and Karaba, F. (2014). Solutions to the exploration/exploitation dilemma: networks as a new level of analysis. International Journal of Management Reviews, 16, pp. 172-193.

Stienstra, M., Baaij, M., Van Den Bosch, F.a.J. and Volberda, H. (2004). Strategic renewal of Europe's largest telecom operators (1992-2001): from herd behaviour towards strategic choice. European Management Journal, 22, pp. 257-262.

Stinchcombe, A.L. (1965). Social structure and organizations. In March, J.G. (ed.), Handbook of Organizations. Chicago: Rand McNally.

Stopford, J.M. and Baden-Fuller, C. (1994). Creating corporate entrepreneurship. Strategic Management Journal, 15, pp. 521-536.

Teece, D.J., Pisano, G. and Shuen, A. (1997). Dynamic capabilities and strategic management. Strategic Management Journal, 18, pp. 509-534.

Teixeira, E.D.O. and Werther, W.B. Jr (2013). Resilience: continuous renewal of competitive advantages. Business Horizons, 56, pp. 333-342.

Teng, B.-S. (2007). Corporate entrepreneurship activities through strategic alliances: a resource-based approach toward competitive advantage. Journal of Management Studies, 44, pp. 119-142.

Thorgren, S., Wincent, J. and Ortqvist, D. (2010). Unleashing synergies in strategic networks of SMEs: the influence of partner fit on corporate entrepreneurship. International Small Business Journal, 30, pp. 453-471.

Tippmann, E., Scott, P.S. and Mangematin, V. (2014). Stimulating knowledge search routines and architecture competences: the role of organizational context and middle management. Long Range Planning, 47, pp. 206-223.

Tranfield, D., Denyer, D. and Smart, P. (2003). Towards a methodology for developing evidence-informed management knowledge by means of systematic review. British Journal of Management, 14, pp. 207-222.

Uhlaner, L.M., Van Stel, A., Duplat, V. and Zhou, H. (2013). Disentangling the effects of organizational capabilities, innovation and firm size on SME sales growth. Small Business Economics, 41, pp. 581-607.

Verbeke, A., Chrisman, J.J. and Yuan, W. (2007). A note on strategic renewal and corporate venturing in the subsidiaries of multinational enterprises. Entrepreneurship Theory and Practice, 31, pp. 585-600.

Volberda, H. (1996). Towards the flexible form: how to remain vital in hypercompetititve environments. Organization Science, 7, pp. 359-374.

Volberda, H. (1998). Building the Flexible Firm. Oxford: Oxford University Press.

Volberda, H. and Baden-Fuller, C. (2003). Strategic renewal processes in multi-unit firms: generic journeys of change. In Chakravarthy, B.S., Mueller-Stewens, G., Lorange, P. and Lechner, C. (eds), Strategy Process: Shaping the Contours of the Field. Oxford: Blackwell, pp. 208232.

Volberda, H. and Lewin, A. (2003). Co-evolutionary dynamics within and between firms: from evolution to coevolution. Journal of Management Studies, 40, pp. 2111-2136.

Volberda, H., Baden-Fuller, C. and Van Den Bosch, F.a.J. (2001a). Mastering strategic renewal: mobilising renewal journeys in multi-unit firms. Long Range Planning, 34, pp. 159-178. 
Volberda, H., Van Den Bosch, F.a.J., Flier, B. and Gedajlovic, E. (2001b). Following the herd or not? Long Range Planning, 34, pp. 209-229.

Wang, C.L. and Chugh, H. (2014). Entrepreneurial learning: past research and future challenges. International Journal of Management Reviews, 16, pp. 24-61.

Whitney, J.O. (1996). Strategic renewal for business units. Harvard Business Review, 74, pp. 84-98.

Wooldridge, B. and Floyd, S.W. (1990). The strategy process, middle management involvement, and organizational performance. Strategic Management Journal, 11, pp. 231241.

Zahra, S.A. (1993). Environment, corporate entrepreneurship, and financial performance: a taxonomic approach. Journal of Business Venturing, 8, pp. 319-340.

Zahra, S.A. (1996). Governance, ownership, and corporate entrepreneurship: the moderating impact of industry technological opportunities. Academy of Management Journal, 39, pp. 1713-1735.
Zollo, M. and Winter, S.G. (2002). Deliberate learning and the evolution of dynamic capabilities. Organization Science, 13, pp. 339-351.

\section{Supporting Information}

Additional Supporting Information may be found in the online version of this article at the publisher's website:

Appendix S1. Summary of selected strategic renewal research (Word document)

Please note: Blackwell Publishing are not responsible for the content or functionality of any supporting materials supplied by the authors. Any queries (other than missing material) should be directed to the corresponding author for the article. 